\title{
Ameliorated Effects of Verapamil on Hepatotoxicity Induced by Ethanol and Carbon Tetrachloride
}

\author{
Hanaa Fathy Waer ${ }^{1 *}$, Nomani Abdelhamid Nomani ${ }^{2}$ and Eman Rizk Elbealy ${ }^{3}$ \\ ${ }^{1}$ Atomic Energy Authority, National Center for Radiation Research and Technology, Cairo, Egypt - Madient Naser Ahmed el Zomor St 8th sector \\ ${ }^{2}$ Al Azhar University, Faculty of Science, Zoology Department \\ ${ }^{3}$ Khalid University, Girls Education Center, College of Science, Abha - Kingdom of Saudi Arab
}

\section{Abstract}

Background: Liver fibrosis progresses to cirrhosis in several settings for example, alcoholic hepatitis and produce hepatocellular dysfunction, which is also a risk factor for hepatocellular carcinoma.

Aim: This study was designated to investigate the potential toxicity of $\mathrm{CCl}_{4}$ initiated by ethanol- as hepatotoxic agents on liver cellular structure glycogen, DNA contents and certain enzymes, and also to evaluate the preventive effect of a certain calcium ions antagonist like verapamil on carbon tetrachloride and ethyl alcohol-induced liver cellular injury in rats.

Materials and methods: Sixty healthy adult male albino rats weighing from 200-220 grams were used in this study. Animals were divided into 4 groups, each consisted of 15 rats: the first was considered the normal control, Group 2 was considered the model control which was given ethanol and $\mathrm{CCl}_{4}$. Group 3,4 were considered the model control which was given verapamil with 2 doses; 40 and $80 \mathrm{mg}$. Samples of the liver were subjected to histopathological, histochemical ultrastructure and biochemical examinations after the restricted times.

Results: Light microscopy revealed that rats given ethanol and $\mathrm{CCl}_{4}$ combined together showed liver cell fibrosis and necrosis, nuclear fragmentation and inflammatory response. Glycogen disorder and DNA damage were also detected. On the other hand, animals that were given verapamil in two doses 40 and 80 reduced hepatocytes degeneration and necrosis, delayed formation of liver fibrosis was detected. There was marked improvement in hepatocytes architecture, glycogen and DNA contents. Electron microscopic and biochemical studies seem to confirm these findings.

Conclusion: The present findings suggested that treatment with Verapamil significantly reverses hepatotoxic dysfunctions induced by $\mathrm{CCl}_{4}$ and ethanol combination and it seems to be dose dependent.

Keywords: Collagen; DNA; Glycogen; Liver; Rat; Verapamilenzymes-electron microscope

\section{Introduction}

Liver fibrosis is the main complication of chronic liver disease and leads eventually to cirrhosis. It is characterized by an excessive deposition of extra cellular matrix (ECM) components in the liver parenchyma. Certain collagen types deposit around the sinusoidal cell layer and re-organization of various ECM molecules results in alterations in the composition of the fibrotic matrix, with deterioration of hepatic functions [1]. The main causes of liver fibrosis are infection with hepatitis B or C, alcohol abuse, and non-alcohol steatohepatitis; leading to accumulation of ECM proteins, which distorts the hepatic architecture by forming a fibrous scar, and subsequent development of nodules of regenerating hepatocytes defines cirrhosis [2].

Alcoholic liver remains one of the most common causes of chronic liver diseases in the world [3]. It is well known that ethanol administration can elicit disturbances in the delicate balance between the pro and antioxidant system of the organism; leading to oxidative stress which is a reason of enhanced lipid per oxidation and change in structure and function of other important cellular components such as protein and DNA [4]. Moreover, ethanol induces hypoxia especially in the pericenteral zone of the liver acinus [5].

Carbon tetrachloride $\left(\mathrm{CCl}_{4}\right)$, which is a classic hepatotoxin, causes acute reversible liver injury characterized by centrilobular necrosis, followed by hepatic regeneration and repair. This liver injury is attributed to inflammatory responses originating from $\mathrm{CCl}_{4}$-derived free radical formation in the liver and activation of non-parenchymal cells that release a variety of inflammatory cytokines in response to several radical species. Hepatic inflammation provoked by long-term treatment with $\mathrm{CCl}_{4}$ is believed to induce hepatic fibrosis through ongoing hepatocytic necrosis and production of fibrogenic cytokines acting on fibroblasts, including activated hepatic stellate cells (HSCs) which normally exist in a quiescent state, but become activated following liver injury causing excess production of ECM [6]. Within the body, $\mathrm{CCl}_{4}$ breaks down to highly toxic trichloromethyl $\left(\mathrm{CCl}_{3}\right)$ and trichloromethyl peroxyl $\left(\mathrm{CCl}_{3} \mathrm{O}_{2}\right)$ free radicals by cytochrome P450 enzyme and causes damage to hepatocytes [7]. Thus, chemicals known to induce isoenzymes of cytochrome $\mathrm{P} 450$ such as ethanol have been shown to strengthen hepatotoxicity of $\mathrm{CCl}_{4}$ [8] and its chronic ingestion is involved in fibrosis and cirrhosis, resulting in greater liver damage than with either agent alone [9], therefore ethanol was recommended to be used in this study to increase activation of

*Corresponding author: Dr. Hanaa F. Waer, 87 Abdel-Shafy Mohamed, Hay ElZohor, 7th sector, 2nd level, Madinet Nasr, Cairo, Egypt, Tel. +201006950192 +966563535597; E-mail: hwaer33@hotmail.com

Received March 05, 2012; Accepted April 11, 2012; Published April 15, 2012

Citation: Waer HF, Nomani NA, Elbealy ER (2012) Ameliorated Effects of Verapamil on Hepatotoxicity Induced by Ethanol and Carbon Tetrachloride. J Cyto Histol 3:142. doi:10.4172/2157-7099.1000142

Copyright: (c) 2012 Waer HF, et al. This is an open-access article distributed unde the terms of the Creative Commons Attribution License, which permits unrestricted use, distribution, and reproduction in any medium, provided the original author and source are credited. 
$\mathrm{CCl}_{4}$. Verapamil is a calcium channel-blocker widely used as an antiarrhythmic agent, treatment of hypertension, ischemic heart disease, and hypertrophic cardiomyopathy. Verapamil's mechanism in all cases is to block voltage-dependent calcium channels [10]. Verapamil is also used in cell biology as an inhibitor of drug efflux pump proteins such as P-glycoprotein. This is useful as many tumor cell lines over express drug efflux pumps, limiting the effectiveness of cytotoxic drugs or fluorescent tags. It is also used in fluorescent cell sorting for DNA content, as it blocks efflux of a variety of DNA-binding fluorophores such as Hoechst 33342. Radioactively-labelled verapamil and positron emission tomography can be used to measure P-glycoprotein function [11]. The present pathological and histochemical research aimed to study the effect of verapamil on the hepatotoxicity induced by $\mathrm{CCl}_{4}$ and ethanol combined together.

\section{Materials and Methods}

\section{Drugs, doses and route of administration}

Drugs and chemicals used in this study were used according to $\mathrm{Xu}$ et al. [12].

A) $40 \% \mathrm{CCl}_{4}$ (98.8\% purity) was prepared freshly $\left(40.5 \mathrm{ml} \mathrm{CCl}_{4}+\right.$ $59.5 \mathrm{ml}$ olive oil) and injected subcutaneously at a dose of $1 \mathrm{ml} / \mathrm{kg}$ body weight, three times a week for three weeks. $\mathrm{CCl}_{4}$ was obtained from Sigma Company.

B) $10 \%$ Ethanol was freshly prepared in drinking water. Animals were given for 4 weeks. Ethanol was obtained from Mark Company.

C) Verapamil was prepared in two different doses; $40 \mathrm{mg} / 100$ $\mathrm{ml} \mathrm{H}_{2} \mathrm{O}$ and $80 \mathrm{mg} / 100 \mathrm{ml} \mathrm{H}_{2} \mathrm{O}$ and given in drinking water for 1 month. Verapamil hydrochloride tablets were purchased from Center Medicine Limited Company (Tianjing, China).

\section{Animals' maintenance and grouping}

Sixty healthy adult male albino rats weighing from 200-220 gram were used in this study, all animal were housed under standard conditions and received human care in compliance with institutional guidelines, they were kept under good ventilation, fed on standard laboratory diet, and supplied with water ad libitum. They were divided into four groups, each consisted of 15 rats: Group I considered the normal control; Group II considered the model control which was given $10 \%$ ethanol alone in drinking water by using oral tube for a week, followed by subcutaneous injection of $40 \% \mathrm{CCl}_{4}$ combined with $10 \%$ ethanol in drinking water for 3 weeks; Group III was given combined ethanol- $\mathrm{CCl}_{4}$ and then they were treated with $40 \mathrm{mg}$ verapamil. 40 mg verapamil therapeutic were treated as group II, and then they were treated with verapamil in drinking water $\left(40 \mathrm{mg} / 100 \mathrm{ml} \mathrm{H}_{2} \mathrm{O}\right.$ for one month) by using oral tube and Group IV was given combined ethanol- $\mathrm{CCl}_{4}$ and then they were treated with $40 \mathrm{mg}$ verapamil. $40 \mathrm{mg}$ verapamil therapeutic treated as group II, and then they were treated with verapamil in drinking water $\left(80 \mathrm{mg} / 100 \mathrm{ml} \mathrm{H}_{2} \mathrm{O}\right.$ for one month) by using oral tube.

Blood sampling: Blood samples were collected from rats after dissection by cardiac puncture. All samples were divided into two parts. One of them was kept in heparinzed tubes to measure plasma cholesterol. Whereas, other samples were centrifuged at $3000 \mathrm{rpm}$ for 15 minutes to separate serum for determination of AST and ALT.

Tissue sampling: After dissection, the liver was divided into three parts; one of them was kept in carnoy fixative for 2-3 hours for histopathological and histochemical purposes [13]. The second was kept in $2.5 \%$ gluteraldehyde buffered with $0.1 \mathrm{M}$ phosphate buffer $(\mathrm{pH}$ 7.2) for Transmission Electron Microscope [14]. The last part was kept in deep freezer $\left(-20^{\circ} \mathrm{C}\right)$ for biochemical assays.

\section{Histopathology}

Sections about $5 \mu \mathrm{m}$ thick were exposed to two histological stains:

1) Haematoxyline and eosin (HE staining) for nucleus and cytoplasm examination.

2) Masson trichrome stain for identifying collagen by blue color and scoring fibrosis.

\section{Histochemistry}

1) Glycogen granules in liver sections were detected using Periodic acid Schiff reagent (PAS). Tissue sections were oxidized with periodic acid for 5 minutes, stained with Schiff's reagent for 10-15 minutes then washed in distilled water for 2 minutes, counterstained in haematoxyline, washed in distilled water then differentiated in ammoniated alcohol until blue color appeared and washed in distilled water, followed by dehydration then purified by xylene and mounted. Glycogen granules located in the cytoplasm of the cell were stained with magenta color.

2) DNA contents in liver sections were detected using Feulgen reagent. Sections were treated with $1 \mathrm{~N} \mathrm{HCl}$ at $60^{\circ} \mathrm{C}$ then stained with Schiff's reagent for 20 minutes, dehydrated, purified and mounted. DNA inside the nucleus was stained with purple to red color.

\section{Electron microscope preparation}

Thin slices of liver tissue ranging in size from $0.5 \mathrm{~mm}$ to $1 \mathrm{~mm}$ were fixed in $2.5 \%$ gluteraldehyde buffered with $0.1 \mathrm{M}$ phosphate buffer $(\mathrm{pH}$ 7.2) for 3 hours at room temperature, dehydrated in ascending grades of ethyl alcohol, cleared and then embedded in embedding medium (araldite). Tissue blocks were cut into thin section under LKB Ultra microtome at (800-900Angestron), Sections were then collected on 200 mech copper grids and stained with 5\% uranyl acetate and lead citrate. Finally, sections were examined and photographed with SEO transmission E.M

\section{Biochemical studies :}

AST and ALT assay: AST and ALT were detected according to Reitman and Frankel [15]

Malondialdehyde (MAD) assay: MAD was detected according to Jena BS et al. [16].

Cholesterol Assay: Plasma cholesterol is evaluated according to Beale RN [17]

\section{Results}

\section{Histopathology}

The extent to which the liver was affected by the hepatotoxic factors and verapamil treatment was evaluated by two histological methods; HE staining and Masson's trichrome staining. Histological studies of livers from normal control rats indicated a normal architecture, while in contrast, group treated with $\mathrm{CCl}_{4}$ - ethanol, show remarkable structural changes such as thickness of portal vein, pyknosis and coagulation of the cytoplasm with steatosis (Figure 1). Multifocal necrosis, macro-vacuolated lipidimia and nuclear fragmentation 
Citation: Waer HF, Nomani NA, Elbealy ER (2012) Ameliorated Effects of Verapamil on Hepatotoxicity Induced by Ethanol and Carbon Tetrachloride. J Cytol Histol 3:142. doi:10.4172/2157-7099.1000142

were seen in foamy vacuolated cytoplasm (Figure 2 and 3). Mild amelioration was remarkable in $40 \mathrm{mg}$ verapamil treated group such as fatty degeneration and cytoplasmic granulation despite the wall thickness of the portal vein and vacuolization (Figure 4). The nuclei appeared to be in normal mitotic state; some were contracted and spherical with one or two permanent nucleoli while others showed hyper proliferation including abnormal nuclear division (tri and tetrapolar divisions) (Figure 5). Dead cell containing nuclear pyknosis was stained by brightly pink color (Figure 6) and stand out from other cells due to the degeneration of structural proteins which form a compact homogenous mass with progressively clumping heterochromatin. Much more improvement occurred in the $80 \mathrm{mg}$ verapamil therapeutic group (Figures 7,8) including well organized lobular architecture with normal portal vein and rearrangement of hepatic acini that appeared as those in the normal hepatic architecture. A well-developed cell structure with granulated cytoplasm, rounded activated nucleus, and fatty changes can be detected.

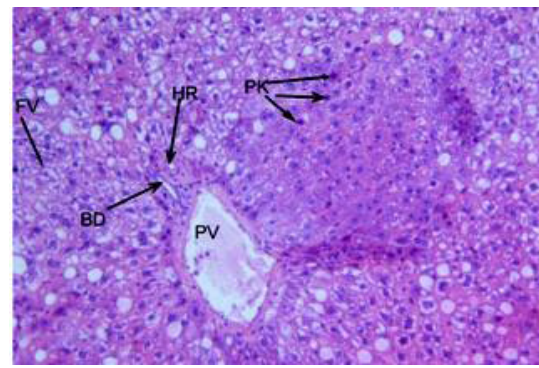

Figure 1: A photomicrograph of liver section from group 2 showing thicknes of portal vein (PV), hepatic artery (HR) and bile ductule (BD), steatosis and foamy vacuoles (FV) with pyknotic stage (PK). (HE, 200X).

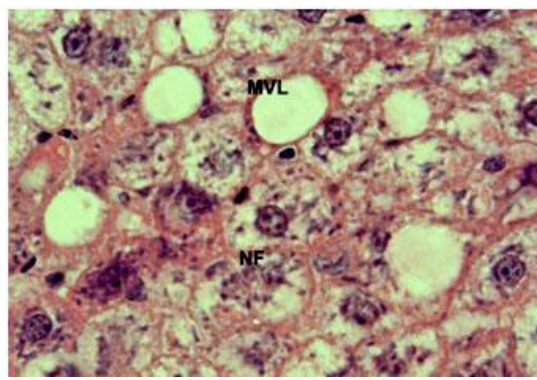

Figure 2: A photomicrograph of liver section from group 2 showing macrovacuolated lipidmia (MVL) and nuclear fragmentation (NF). (HE, 1000X).

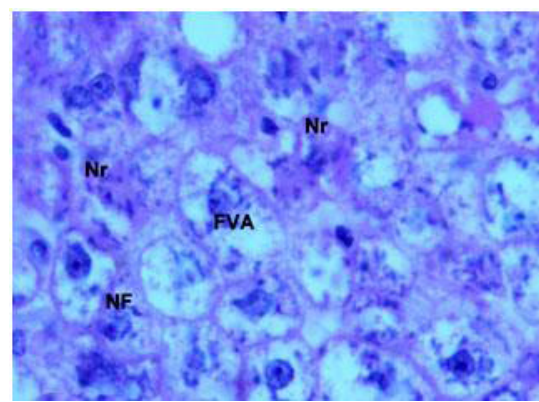

Figure 3: A photomicrograph of liver section from group 2 showing cytoplasm rich in necrotic cells (Nr), foamy vacuolated cytoplasm (FV) and nuclear fragmentation (NF). (HE, 1000X).

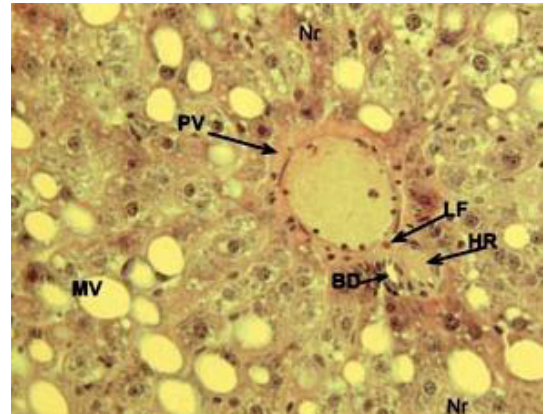

Figure 4: A photomicrograph of liver section from group 3 showing portal vein $(\mathrm{PV})$ filled with vacuoles, portal triad surrounded by connective tissue and containing hepatic artery (HR) and bile ductule (BD) with infiltrated lipofusin (LF), macro-vacuoles (MV) containing necrosis (Nr) (HE, 200X)

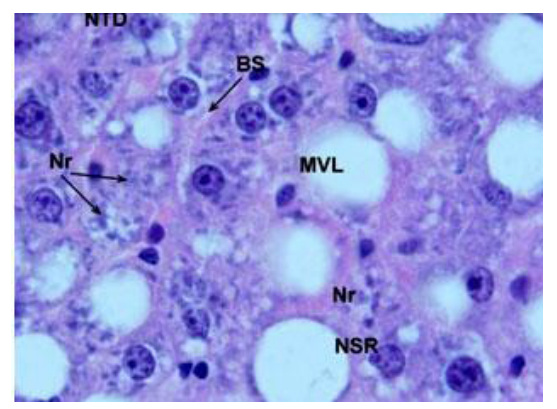

Figure 5: A photomicrograph of liver section from group 3 showing nuclear signet ring (NSR), nuclear tri-polar division (NTD) and necrosis (Nr). (HE, 1000X).

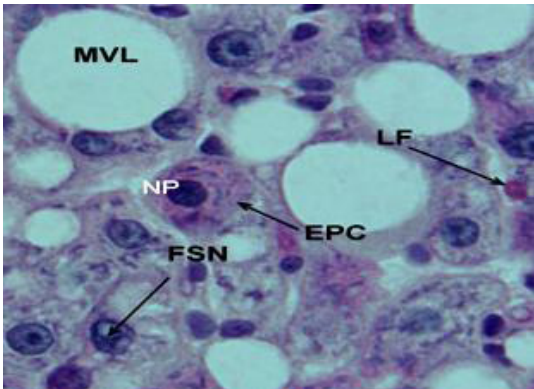

Figure 6: A photomicrograph of liver section from group 3 showing dead cell containing nuclear pyknosis (NP) (dark material) and homogenous cytoplasmic (Eosinophilic pink color) (EPC). Note lipofusin (LF) and shutting fat to nucleus (SFN). (HE, 1000X).

Prominent accumulation of collagen fibers around portal vein and portal triad were clearly detected in $\mathrm{CCl}_{4}$-ethanol-treated group causing thickness of the walls of both central and portal veins (Figure 9). Fibrous septa with hepatic nodules were observed (Figure 10). On the other hand, collagen fibers around the portal vein and blood capillaries were less condensed in the $40 \mathrm{mg}$ verapamil group (Figure 11 and 12). These alterations were fully reduced in the $80 \mathrm{mg}$ verapamil therapeutic group with no appearance of collagen fibers around the portal vein and portal trades (Figures 13 and 14).

\section{Histochemical study}

Methods used in this study were used to detect glycogen using Periodic acid Schiff technique and DNA content by Feulgen reaction. 
Citation: Waer HF, Nomani NA, Elbealy ER (2012) Ameliorated Effects of Verapamil on Hepatotoxicity Induced by Ethanol and Carbon Tetrachloride. J Cytol Histol 3:142. doi:10.4172/2157-7099.1000142

Glycogen is found in the form of large amounts of aggregated clumps in cytoplasm of hepatic cells in normal livers, characterized by a deeply reddish stain. In the $\mathrm{CCl}_{4}$-ethanol-injected group, glycogen content of the hepatocytes revealed a marked depletion in glycogen content when compared with normal control liver cells (Figure 15). There was a gradual increase in glycogen content in the $40 \mathrm{mg}$ verapamil group, but still less pronounced than in normal controls (Figure 16). Finally, glycogen seemed to return to its normal pattern in the $80 \mathrm{mg}$ verapamil therapeutic group (Figure 17).

DNA content of the model group injected with $\mathrm{CCl}_{4}$-ethanol (Figure 18) showed marked increase and condensation. Slight improvement in DNA content can be recognized in the group treated with $40 \mathrm{mg}$ verapamil (Figure 19). Treatment with $80 \mathrm{mg}$ verapamil

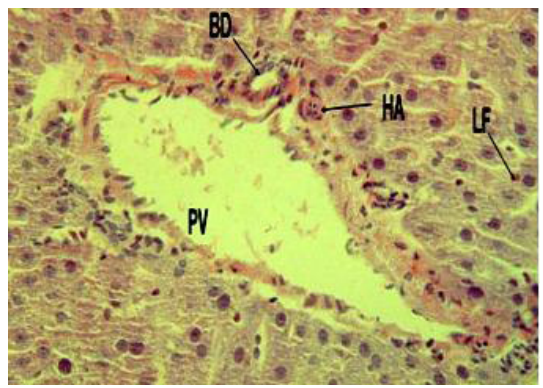

Figure 7: A photomicrograph of liver section from group 4 showing normal portal vein $(P V)$ with bile ductule (BD) and hepatic artery $(H A)$ with lipofusin (LF). (HE, 200X).

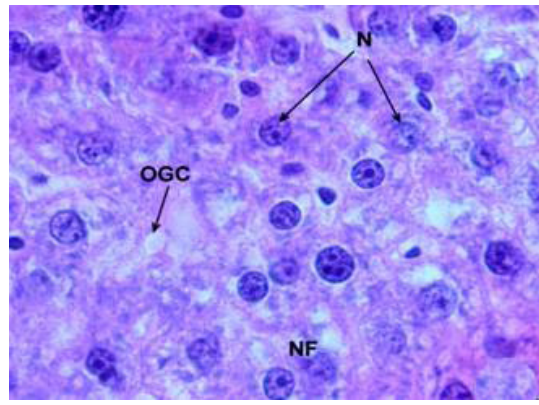

Figure 8: A photomicrograph of liver section from group 4 showing normal mitotic figure and rounded nucleus $(\mathrm{N})$ with nuclear fragmentation (NF) (HE, 1000X)

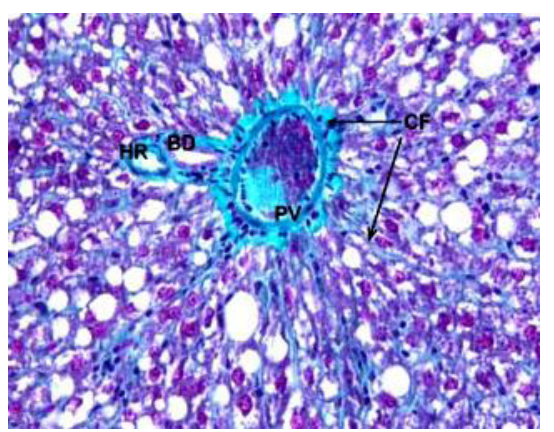

Figure 9: A photomicrograph of liver section from group 2 showing wall thickness of portal vein (PV) filled with condensed small particles. Collagen fibers (CF) surrounded the portal vein and extended in between the hepatocytes throughout the sinusoids. (Masson trichrome stain, 400X).

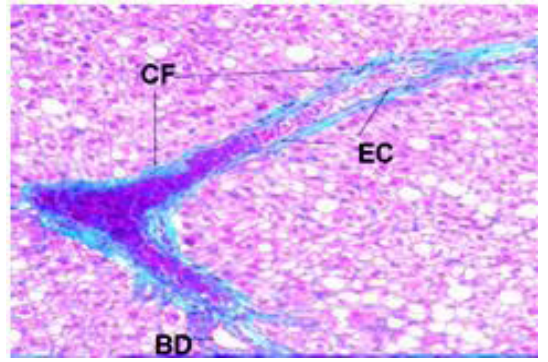

Figure 10: A photomicrograph of liver section from group 2 showing blood capillary surrounded with collagen fibers (CF). (Masson trichrome stain, 400X)

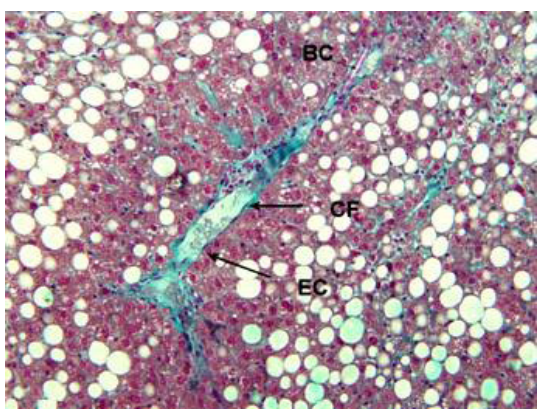

Figure 11: A photomicrograph of liver section from group 3 showing slightly normal blood capillary (BC) lined with endoepithelial cells (EC) and surrounded with collagen fibers. (Masson trichrome stain, 400X).

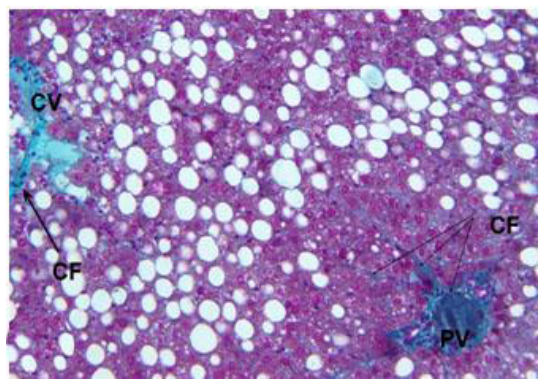

Figure 12: A photomicrograph of liver section from group 3 showing slight extension of collagen fibers from portal areas. (Masson trichrome stain, 400X)

showed more obvious improvement in DNA content with increasing number of nuclei (Figure 20).

\section{Ultrastructure and biochemical studies}

Electron micrographs of liver sections of group 2 show vacuolated cytoplasm (cy) (Figure 25-28) with abundance of collagen (CF) fiber, malformed mitochondria and increased amount of lipid particles (LD). Lipid can also be seen inside the destructive nucleus (Figures 21-24). On the other hand a gradual amelioration is seen as dose dependant in other treated groups with verapamil.

\section{Biochemical assay}

Aspartate aminotransferase and Alanine aminotransferase ALT, AST levels: Data in (Table 3) and (Figures 29, 30) show the effect of (40 and $80 \mathrm{mg} / 100 \mathrm{ml} \mathrm{H}_{2} \mathrm{O}$ ) verapamil on the activity of serum (ALT and AST per U/L). A highly significant increase of serum ALT and AST in 
Citation: Waer HF, Nomani NA, Elbealy ER (2012) Ameliorated Effects of Verapamil on Hepatotoxicity Induced by Ethanol and Carbon Tetrachloride. J Cytol Histol 3:142. doi:10.4172/2157-7099.1000142

Page 5 of 11

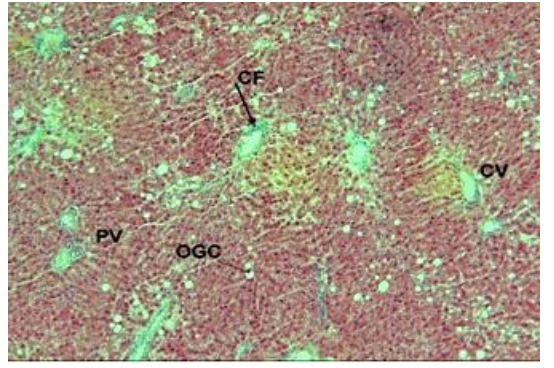

Figure 13: A photomicrograph of liver section from group 4 showing norma central vein (CV) with normal collagen fibers (CF). Hepatic acini rearranged with slightly narrow sinusoids and over granulated cytoplasm (GC). (Masson trichrome stain, 100X).

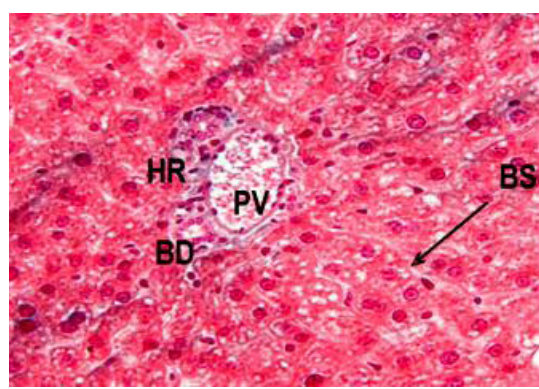

Figure 14: A photomicrograph liver section from group 4 showing normal portal vein $(\mathrm{PV})$ with more improvement of portal triad and full reduction of collagen fibers. (Masson trichrome stain, 400X).

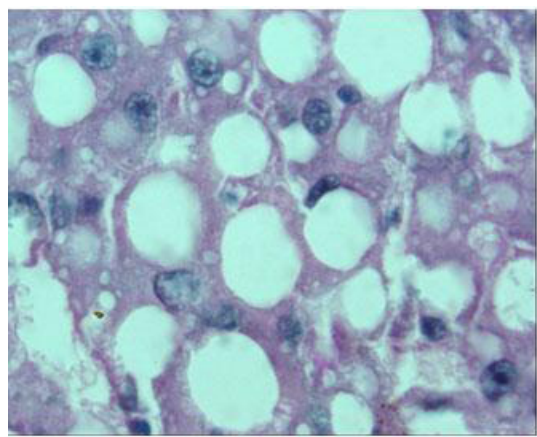

Figure 15: A photomicrograph of liver section from group 2 showing glycogen depletion. (PAS stain, 1000X).

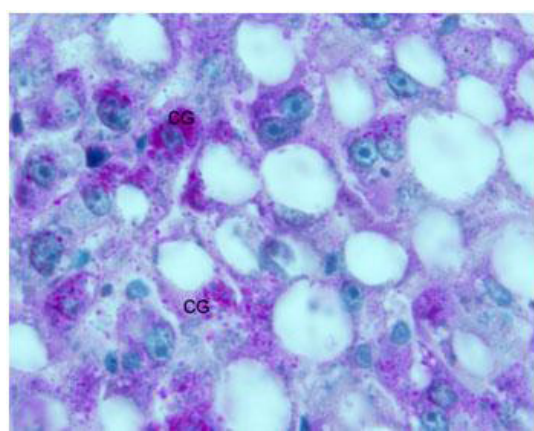

Figure 16: A photomicrograph of liver section from group 3 showing glycogen $(G)$ in normal distribution filling some hepatocytes to form clumps. (PAS stain, 1000X)

\begin{tabular}{|c|c|c|}
\hline & AST (U/L) & ALT(U/L) \\
\hline Groups Treat & Mean \pm S.E & Mean \pm S.E \\
\hline Control & $153 \pm 8$ & $49.8 \pm 0.84$ \\
\hline Ethanol and CCl4 & $430.11^{\mathrm{a}+} \pm 5$ & $159^{\mathrm{a}++} \pm 4$ \\
\hline Ethanol $+\mathrm{CCl}_{4}+40 \mathrm{mg}$ verapamil & $299^{\mathrm{a}+} \pm 5$ & $94.2^{\mathrm{a}+} \pm 7$ \\
\hline Ethanol $+\mathrm{CCl}_{4}+80 \mathrm{mg}$ verapamil & $197^{\mathrm{a}} \pm 9$ & $69.8^{\mathrm{a}} \pm 2$ \\
\hline
\end{tabular}

Each value is the mean of 5 records $\pm S E,{ }^{a++} \mathrm{P}<0.001$ versus normal control ${ }^{a+} \mathrm{P}<0.01$ and a $\mathrm{P}<0.05$ v.s. ethanol $+\mathrm{CCl}_{4}$

Table 1: The effect of verapamil on serum AST and ALT (U/L) in adult albino rats treated by ethanol and $\mathrm{CCl}_{4}$.

\begin{tabular}{|c|c|c|}
\hline & Hydroxyproline ( $\mu \mathrm{g} / \mathrm{g})$ & MDA $(\mathrm{nmol} / \mathrm{g})$ \\
\hline Groups & Mean \pm S.E & Mean \pm S.E \\
\hline Control & $0.3083 \pm 0.004$ & $14.4 \pm 0.3$ \\
\hline Ethanol and $\mathrm{CCl} 4$ & $0.923^{a++} \pm 0.05$ & $146.7^{\mathrm{a}++} \pm 2.6$ \\
\hline $\begin{array}{c}\text { Ethanol }+\mathrm{CCl} 4+40 \mathrm{mg} \\
\text { verapamil }\end{array}$ & $0.75^{\mathrm{a}+} \pm 0.023$ & $103.6^{\mathrm{a}+} \pm 7.8$ \\
\hline $\begin{array}{c}\text { Ethanol }+\mathrm{CCl} 4+80 \mathrm{mg} \\
\text { verapamil }\end{array}$ & $0.5143^{\mathrm{a}} \pm 0.001$ & $56.2 \pm 0.3$ \\
\hline
\end{tabular}

Each value is the mean of 5 records $\pm S E, a++P<0.001$ versus normal control $\mathrm{a}+\mathrm{P}<0.01$ and $\mathrm{a} \mathrm{P}<0.05$ v.s. ethanol $+\mathrm{CCl} 4$

Table 2: The effect of verapamil on Hydroxyproline $(\mu \mathrm{g} / \mathrm{g})$ and Malondialdehyde MDA (nmol/g) level of liver homogenate in adult albino rats treated by ethanol and $\mathrm{CCl}_{4}$

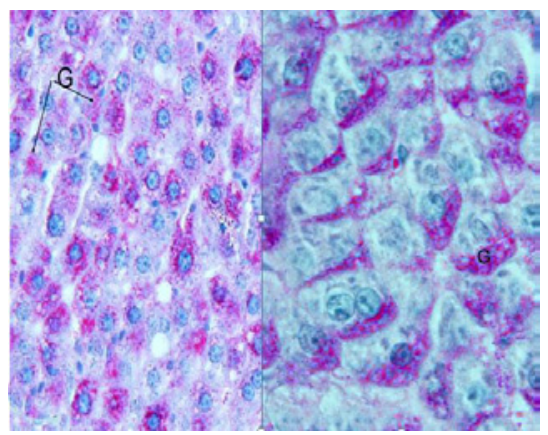

Figure 17: (a) A photomicrograph of liver section from group 4 showing glycogen granules (G) returning normal. (PAS stain, 400X). (b): higher magnification. (PAS stain, 1000X)

rats treated with ethanol and $\mathrm{CCL}_{4}$ was obtained compared to other treated groups. Treatment with 40 and $80 \mathrm{mg}$ verapamil ameliorate ALT and AST.

Malondialdehyde and Hydroxyproline assay: Data presented in (Table 2) and (Figure 31) illustrate the effect of (40 and $80 \mathrm{mg} / 100 \mathrm{ml}$ $\mathrm{H}_{2} \mathrm{O}$ ) verapamil on MDA levels of liver homogenate in adult albino rats. The result showed a highly significant increase of MDA level in a group treated with $10 \%$ ethanol and $40 \% \mathrm{CCl}_{4}(146.7 \pm 2.6)(\mathrm{nmol} / \mathrm{g})$ compared to control $(14.4 \pm 0.3)(\mathrm{nmol} / \mathrm{g})$ or both $(40 \mathrm{mg} / 100 \mathrm{ml}$ $\mathrm{H}_{2} \mathrm{O}$ and $80 \mathrm{mg} / 100 \mathrm{ml} \mathrm{H} \mathrm{H}_{2}$ ) verapamil as recorded in their mean values $(103.6 \pm 7.8)(\mathrm{nmol} / \mathrm{g})$ and $(56.2 \pm 0.3)(\mathrm{nmol} / \mathrm{g})$ respectively. 
Citation: Waer HF, Nomani NA, Elbealy ER (2012) Ameliorated Effects of Verapamil on Hepatotoxicity Induced by Ethanol and Carbon Tetrachloride. J Cytol Histol 3:142. doi:10.4172/2157-7099.1000142

On the other hand data presented in table 2 and figure 32 explain the effect of different treatment on hydroxyproline of liver homogenate in adult albino rats. The results display a highly significant increase of hydroxyproline in group treated by $10 \%$ ethanol and $40 \% \mathrm{CCl}_{4}(0.923$ $\pm 0.05)(\mu \mathrm{g} / \mathrm{g})$ compared to control $(0.3083 \pm 0.004)(\mu \mathrm{g} / \mathrm{g})$ or 40 and 80 mg verapamil group $(0.75 \pm 0.023)(\mu \mathrm{g} / \mathrm{g})$ and $(0.5143 \pm 0.001)(\mu \mathrm{g} / \mathrm{g})$.

Cholesterol level: Data presented in (Table 3) and (Figure 33) represented the level of total plasma cholesterol according to the different treatments in adult albino rats. Highly significant increase in plasma cholesterol level was observed in group of animals treated with $10 \%$ ethanol and $40 \% \mathrm{CCl}_{4}(5.3 \pm 0.32)(\mathrm{mg} / \mathrm{ml})$ compared to (control) untreated group $(1.2 \pm 0.1)(\mathrm{mg} / \mathrm{ml})$ and verapamil treated groups. More decrease in plasma cholesterol was detected when ethanol and $\mathrm{CCl}_{4}$ group was treated by $80 \mathrm{mg} / 100 \mathrm{ml} \mathrm{H}_{2} \mathrm{O}$ in drinking water for one

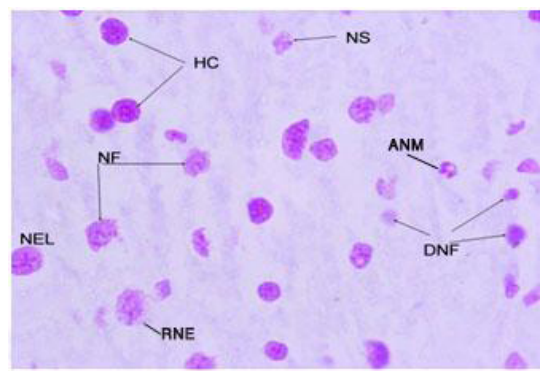

Figure 18: A photomicrograph of liver section from group 2 showing that most DNA in nuclei is hyperchromatism $(\mathrm{HC})$, less nuclear integrity form nuclear shrinkage (NS), nuclear enlargement (NEL), nuclear fragmentation (NF) and disappearance of nuclear feature (DNF). (Feulgen reagent, 1000X).

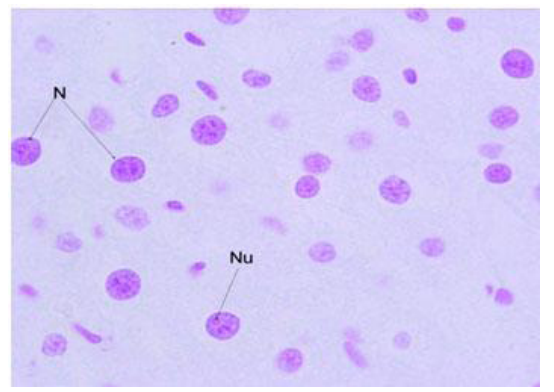

Figure 19: A photomicrograph of liver section from group 3 showing rounded or oval nucleus $(\mathrm{N})$ containing one or two nucleoli $(\mathrm{Nu})$ and improved pattern of DNA inside nucleus. (Feulgen reagent, 1000X).

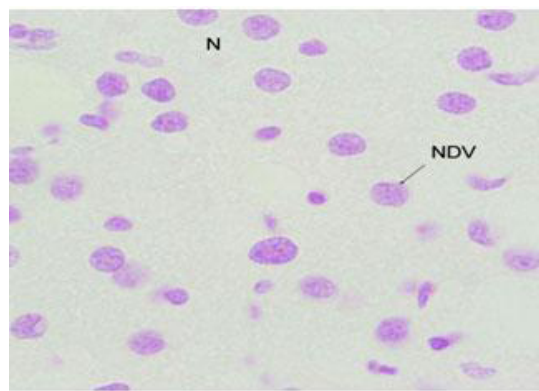

Figure 20: A photomicrograph of liver section from group 4 showing nuclei (N) in nuclear mitotic division (NDV). (Feulgen reagent, 1000X).

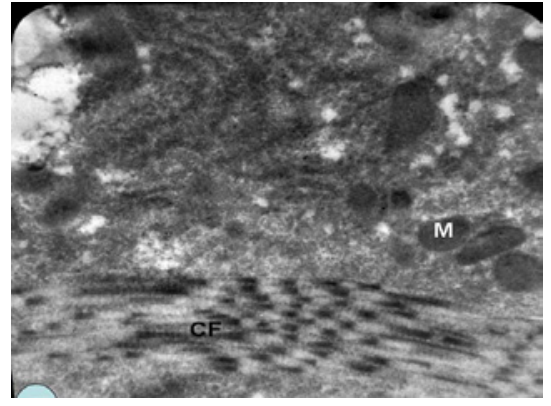

Figure 21: 10000x: Showing vacuolated cytoplasm with abundance of collagen(CF) fiber, and malformed mitochondria.

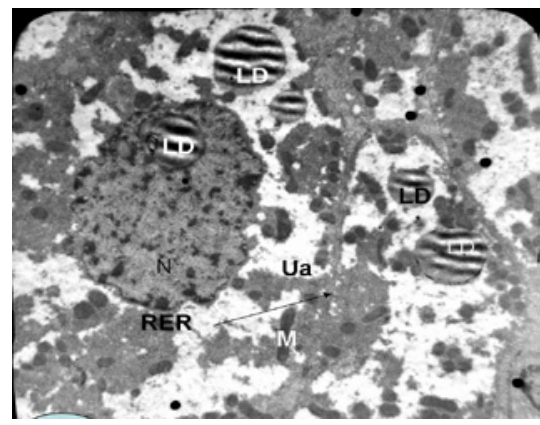

Figure 22: 6000x: Showing increased amount of lipid particle(LD) lipid can also seen inside the destructive nucleus.

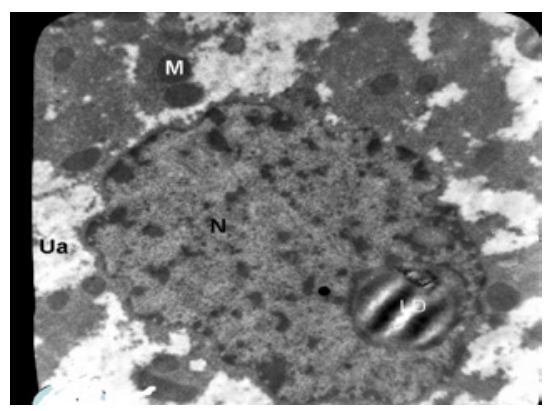

Figure 23: 3000x : High magnification of Figure 22, note lipid particle inside the nucleus.

month $(1.8 \pm 0.03)(\mathrm{mg} / \mathrm{ml})$ than those treated by $40 \mathrm{mg} / 100 \mathrm{ml} \mathrm{H} \mathrm{O}$ $(3.5 \pm 0.2)(\mathrm{mg} / \mathrm{ml})$.

Finally it can be observed that a higher dose of verapamil ( $80 \mathrm{mg})$ proved to be much better than $40 \mathrm{mg}$.

\section{Discussion}

\section{Histopathological discussion}

$\mathrm{CCl}_{4}$ is a hepatotoxin causing liver fibrosis, necrosis and cirrhosis sequentially when administrated. It also results in ballooning, inflammatory infiltration of lymphocytes and hydropic degeneration with a clear cytoplasm and vacuolization [18]. Ethanol alone causes chronic liver disease due to toxicity by generating free radicals [19] and apoptosis [20]. The combination between ethanol and $\mathrm{CCl}_{4}$ result in liver damage greater than cirrhosis caused with either agents alone [9]. Major pathway for ethanol metabolism is alcohol dehydrogenase which 
Citation: Waer HF, Nomani NA, Elbealy ER (2012) Ameliorated Effects of Verapamil on Hepatotoxicity Induced by Ethanol and Carbon Tetrachloride. J Cytol Histol 3:142. doi:10.4172/2157-7099.1000142

acts as a catalyst for the oxidation of ethanol to acetaldehyde, where hydrogen is transferred from ethanol to the cofactor nicotinamide adenine dinucleotide (NAD+); which is converted into the reduced form $(\mathrm{NADH})$. Acetaldehyde is reduced to acetate, which is secreted to the blood stream [21].

Sections taken from control rats showed the normal structure of liver tissue composed of hepatocytes arranged in cords radiating from a central vein in a manner that forms a labyrinth and separated from each other by blood sinusoids, which are nearly equal in size. Polyhedral hepatocytes appear with acidophilic cytoplasm and rounded nuclei with one or two nucleoli.

Results obtained in the present study showed that fat droplets were accumulated in hepatocytes in rats treated with ethanol and $\mathrm{CCl}_{4}$ [22]. This may be due to that $\mathrm{CCl}_{4}$ alone caused accumulation of lipid

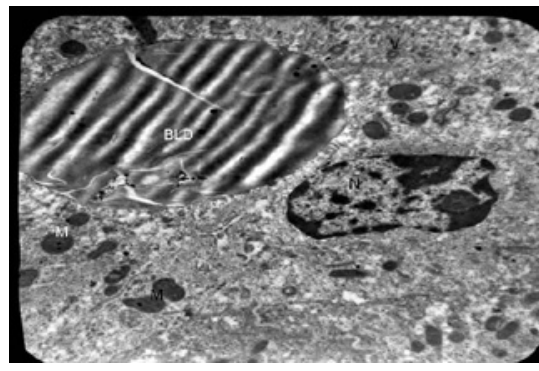

Figure 24: 8000x: Showing an electron micrographs of liver sections.

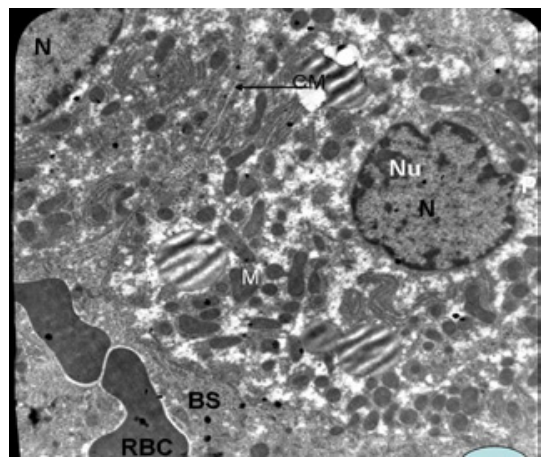

Figure 25: 4000x : Show vacuolated cytoplasm with nearly normal nucleus $(\mathrm{N})$, the mitochondria retain its normality.

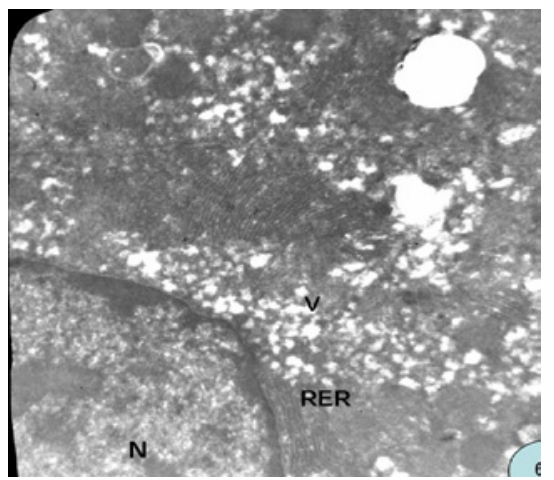

Figure 26: 6000x: Granulatedcytoplasm.

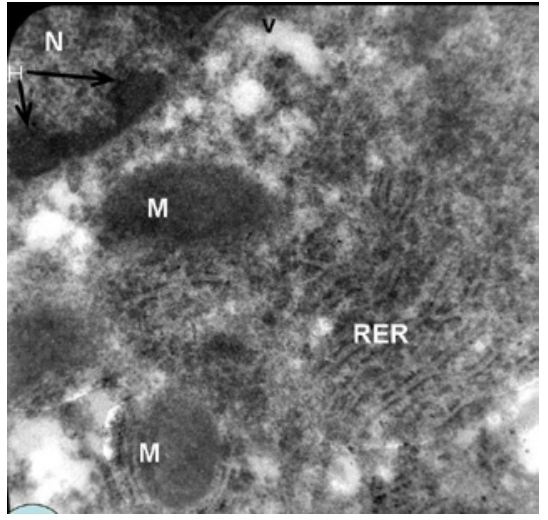

Figure 27: 8000x: Show normal cellular structure.

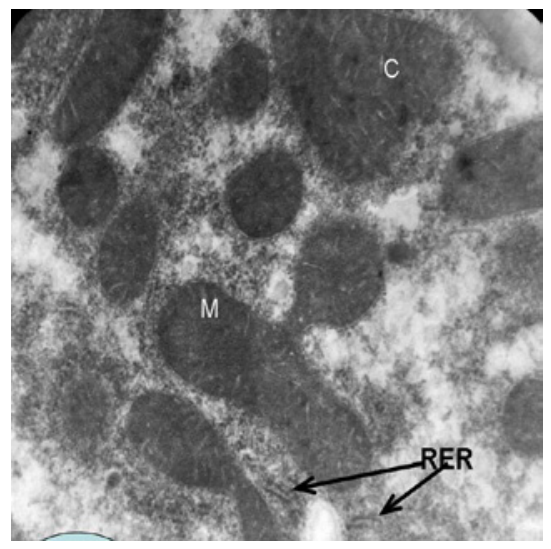

Figure 28: 10000x: Showing high magnification of Fig 27 show normal mitochondrial structure, note double membrane and short creaste.

droplets in cytoplasm of hepatocytes as well; consumption of ethanol alone caused the development of liver steatosis and swelling [23]. The histopathological feature of fat accumulation inside the liver is explained in steps; at the beginning the hepatocytes are present as small vacuoles around the nucleus (microvesicules) which are then filled with multiple fat droplets; later, the size of the vacuoles increases; pushing the nucleus to the periphery of the cell; giving a signet ring appearance (macrovesicular fatty change). These vesicles are well delineated and optically "empty" as fats dissolve during tissue processing. Large vacuoles coalesce, producing fatty cysts which are irreversible lesions [24]. Macro vesicular steatosis is the most common form in alcohol and $\mathrm{CCl}_{4}$ liver disease. Each of ethanol and $\mathrm{CCl}_{4}$ individually contribute in accumulation of fat droplets inside liver according to its metabolism. In alcohol metabolism, the increased NADH promotes the generation of building blocks of fat molecule and reduces the breakdown of fats in liver. Moreover, alcohol contributes to the release of fats from other tissue which are then transported to the liver and enhance the liver uptake of fats circulating in the blood [21]. $\mathrm{CCl}_{4}$ is activated by cytochromes to form trichoromethyl radical $\left(\mathrm{CCl}_{3}\right)$ which can bind to nucleic acid, protein and lipid, thus impairing crucial cellular processes such as lipid metabolism and resulting in steatosis [23].

Pathological alterations in hepatic architecture illustrated in disorganization of the hepatocytes, most hepatic acini were not arranged in definite patterns. The development of vacuoles might be 
Citation: Waer HF, Nomani NA, Elbealy ER (2012) Ameliorated Effects of Verapamil on Hepatotoxicity Induced by Ethanol and Carbon Tetrachloride. J Cytol Histol 3:142. doi:10.4172/2157-7099.1000142

the starting point of cellular autolytic process [25] and "capillarization" which means a change in the phenotype of the sinusoidal endothelial cell to a vascular phenotype with loss of fenestration and formation of an organized basement membrane [26], thus, sinusoids impair the normal bidirectional exchange between the portal venous blood and hepatocytes, leading to substances that are normally metabolized by hepatocytes to bypass the liver and reach the systemic circulation, and prevent substances that are produced in the liver to reach the blood. This process further complicates problems primarily caused by portal hypertension and decreased hepatocellular synthetic function, such as hypo albuminuria and deficiency of coagulation factors [1].

Fibrosis is part of a dynamic process of continuous extracellular matrix (ECM) remodeling in chronic liver injury, which leads to an excessive accumulation of several extracellular proteins and carbohydrates [1]. In the present study, light microscope examination revealed liver fibrosis in the group treated with ethanol- $\mathrm{CCl}_{4}$ as recorded before [27]. Ethanol contributes to increase in liver fibrosis by formation of acetaldehyde, resulting in the formation of reactive oxygen species (ROS) which activate hepatic stellate cells, thus promote fibrogenesis [28]. Beside fibrosis, the collagen fibers in the present study extend and destroy the architecture of liver samples. This was in coincidence with prior investigations $\mathrm{CCl}_{4}$ [29]. Ethanol had a specific role to potentiate the toxicity of $\mathrm{CCl}_{4}$, causing greater liver fibrosis and more damage, where acetaldehyde is responsible for stimulation of collagen biosynthesis. Furthermore, increase in NADH levels result in formation of scar tissue that characterize fibrosis.

Ethanol and $\mathrm{CCl}_{4}$ in the present work contributed in pushing the cell towards "apoptosis", affecting only individual cells, leaving adjacent

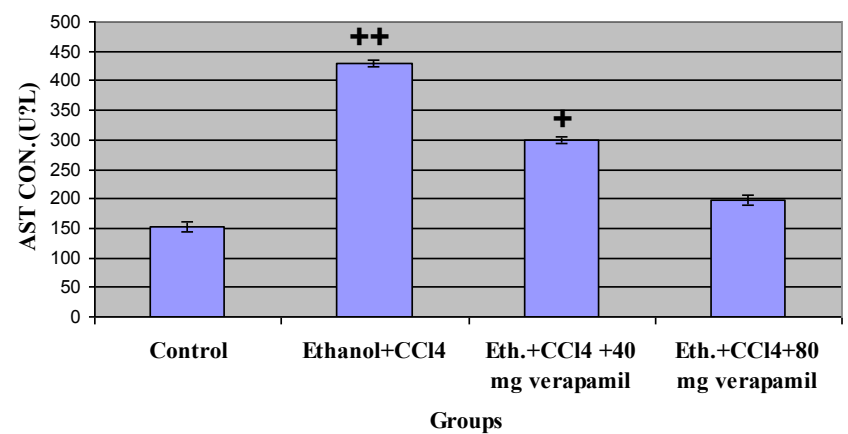

Figure 29: Concentration of ASTase (U/L) in serum of rats after $40 \mathrm{mg}$ and $80 \mathrm{mg}$ verapamil treatments.

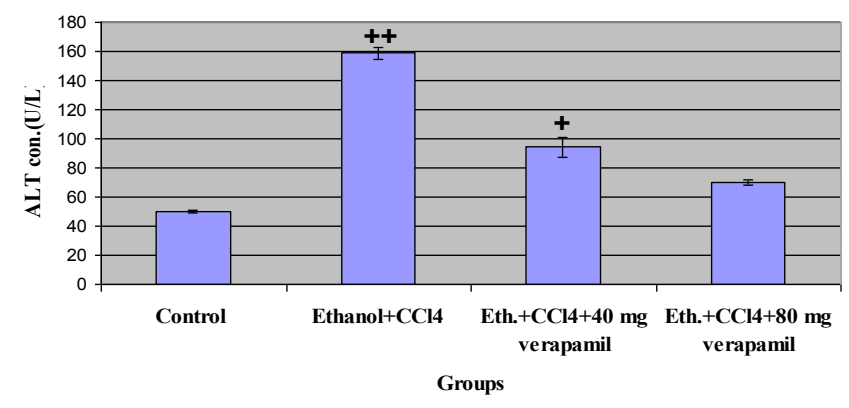

Figure 30: Concentration of ALTase $(\mathrm{U} / \mathrm{L})$ in serum of rats after different treatments.

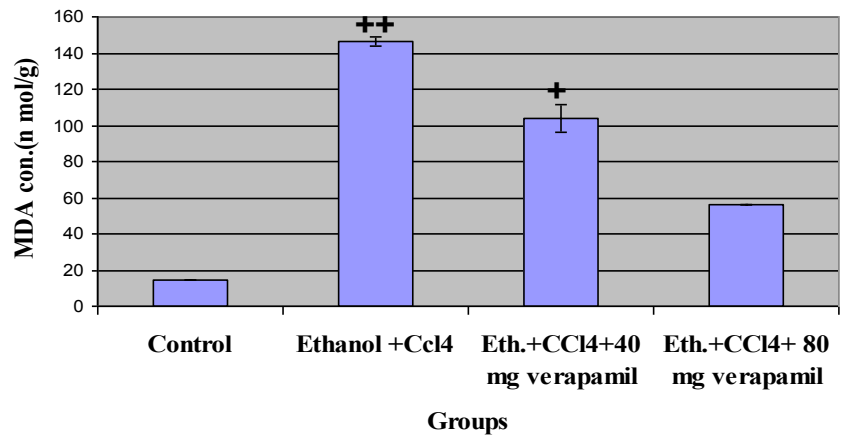

Figure 31: Concentration of Malondialdehyde (nmol/g) in liver homogenate of rats after different treatments.

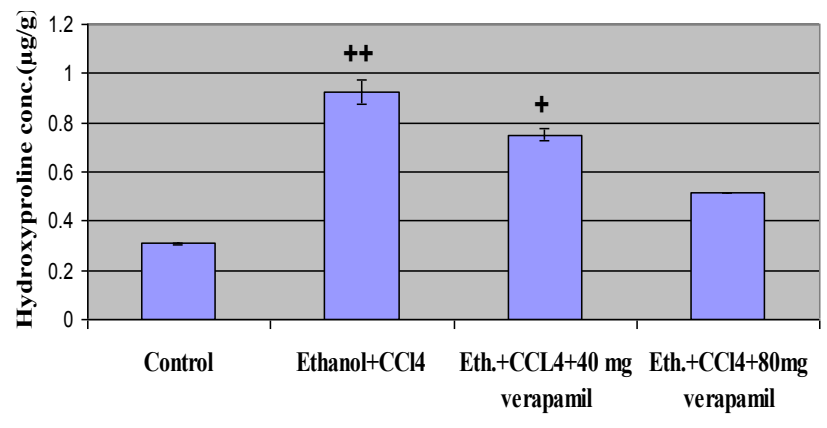

Groups

Figure 32: Concentration of Hydroxyproline $(\mu \mathrm{g} / \mathrm{g})$ in liver homogenate of rats after different treatments.

cells intact. The condensed chromatin, fragmentation and shrinking of nucleus were seen as evidence for apoptosis. This histopathological feature showed morphological changes [30]; the cell body shrinks and looses contact to its neighboring cells, chromatin in nucleus condenses and migrates to the nuclear membrane, and finally the cell is fragmented into compact membrane-enclosed structures, called 'apoptotic bodies' which contain cytosol, condensed chromatin, and organelles. The apoptotic bodies are engulfed by macrophages (scavenging cells) and thus are removed from the tissue without causing an inflammatory response. Proteolytic enzymes mediate the cleavage of DNA into fragments as well as the cleavage of specific protein substrates which determine the integrity and shape of the cytoplasm or organelles. The mechanism of action of apoptosis is known to occur in mitochondria which release cytochrome $\mathrm{c}$ and the endoplasmic reticulum which release calcium [31]. $\mathrm{CCl}_{4}$ causes accumulation of calcium in the nucleus and produce $\mathrm{Ca}^{+2}$ endonuclease fragmentation of DNA.

The study revealed necrosis in liver sections of the group treated with ethanol and $\mathrm{CCl}_{4}$ combined together. Cells undergoing necrosis swell and their organelles break down. They lose membrane integrity, rupture and spill debris that leads to local inflammation which then results in the death of adjacent cells. Necrosis is morphologically distinct from apoptosis and is defined as cell death accompanied by a rapid efflux of cell constituents to the extra cellular space due to a loss of cytoplasmic membrane integrity [32] and it takes place under extremely harmful environmental conditions such as exposure to toxic chemicals and microbial pathogens, and causes inflammation which gives rise to damage to surrounding cells [33]. 
Citation: Waer HF, Nomani NA, Elbealy ER (2012) Ameliorated Effects of Verapamil on Hepatotoxicity Induced by Ethanol and Carbon Tetrachloride. J Cytol Histol 3:142. doi:10.4172/2157-7099.1000142

Concerning the vacuolated cytoplasm (Figure 25), the increase in cell volume is due to the loss of regulating mechanism of the cell to pump out water from the inside. Energy required for this is given by the respiration which is suppressed by $\mathrm{CCl}_{4}$. Swelling of the cell in $\mathrm{CCl}_{4}$ treatment is due to the changed permeability of the cell membrane, since $\mathrm{CCl}_{4}$ is a nonpolar lipophilic substance and results in the changed characteristics of the lipid membrane of both cytoplasm and mitochondria [34].

Results showed increase in the chromatin content in the nuclei of most hepatocytes of rats which received ethanol- $\mathrm{CCl}_{4}$. Heterochromatin predominates over euchromatin and is peripherally emarginated along the inner nuclear membrane. Such situation of chromatin is observed as a change in the nucleus associated with irreversible injury leading to cell death. Moreover, the nuclei of hepatocytes treated with ethanol and $\mathrm{CCl}_{4}$ showed enlargement and nuclear polymorphism which was suggested to have significance as a marker of carcinomous lesions [35].

In the present study, pyknosis was seen in the group treated with ethanol and $\mathrm{CCl}_{4}$, in harmony with the observations showing that $\mathrm{CCl}_{4}$ caused pyknosis of nucleus and necrosis of the liver cells [36]. It is irreversible condensation of chromatin in the nucleus of a cell undergoing programmed cell death or apoptosis and it is followed by fragmentation of the nucleus [37]. Concerning DNA fragmentation, ethanol and $\mathrm{CCl}_{4}$ together have role in increasing DNA degeneration in rat liver as it was induced by both ethanol and $\mathrm{CCl}_{4}[20,38]$ individually.

In the present histopathological study, treatment with two concentration doses (40 and $80 \mathrm{mg}$ ) of calcium channel blocker Verapamil decreased the toxic effect of ethanol and $\mathrm{CCl}_{4}$ in livers of rats. The $80 \mathrm{mg}$ dose of verapamil reduced the collagen fibers, infiltrations, and steatosis, and improved the architecture of hepatocytes and shape of nucleus. Using $40 \mathrm{mg}$ verapamil also showed improvement in liver tissue structure, in spite of the presence of slight thickening and fibrosis in blood vessels walls especially the central veins. Hypertrophy of kupffer cells in blood sinusoid can be explained by increased phagocytic activity in removing debris of dead cells in the stage of regeneration. Slight fibrosis remained surrounding the hepatocytes and extending between them towards neighboring areas and slight dilatation of blood sinusoid was noticed. The results are in accordance with observations which found that the two concentrations of verapamil reduced hepatocytes degeneration, necrosis and delayed the formation of liver fibrosis in rats [12] and confirmed that complex factors (ethanol, $\mathrm{CCl}_{4}$, and high fat diet) caused severe histopathological changes such as steatosis,

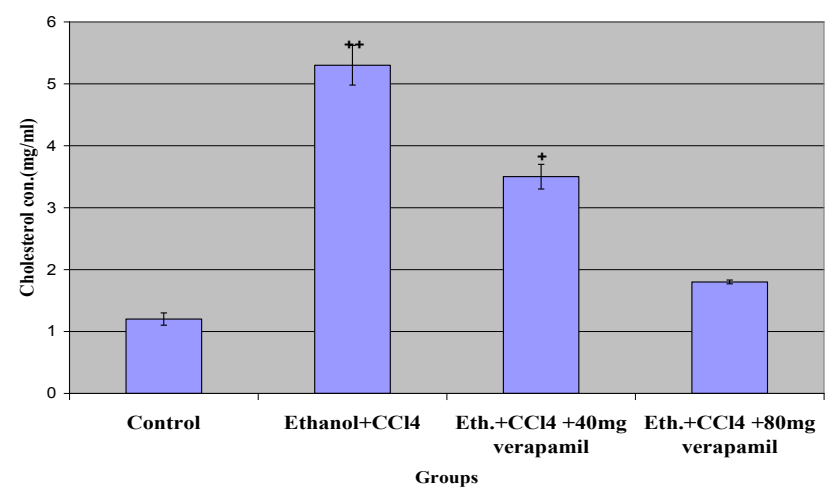

Figure 33: Concentration of plasma cholesterol $(\mathrm{mg} / \mathrm{ml})$ of rats after different treatments.

\begin{tabular}{|r|c|}
\hline & Cholesterol $(\mathrm{mg} / \mathrm{l})$ \\
\hline Groups Treat & Mean \pm S.E \\
\hline Control & $1.2 \pm 0.1$ \\
\hline Ethanol and CCl4 & $5.3^{\mathrm{a}++} \pm 0.32$ \\
\hline Ethanol + CCl4+40 mg verapamil & $3.5^{\mathrm{a}+} \pm 0.2$ \\
\hline Ethanol $+\mathrm{CCl} 4+80 \mathrm{mg}$ verapamil & $1.8^{\mathrm{a}} \pm 0.03$ \\
\hline
\end{tabular}

Each value is the mean of 5 records $\pm S E,{ }^{a++} P<0.001$ versus normal control ${ }^{a+} \mathrm{P}<0.01$ and $\mathrm{a} P<0.05$ v.s. ethanol $+\mathrm{CCl} 4$

Table 3: The effect of verapamil on plasma cholesterol $(\mathrm{mg} / \mathrm{L})$ in adult albino rats treated by ethanol and $\mathrm{CCl}_{4}$.

macrophage infiltration, myofibroblast proliferation, and liver fibrosis which were evident in the disruption of tissue architecture, extension of fibers, large fibrous septa formation, pseudo-lobe separation and accumulation of collagen. These alterations were reduced markedly in the liver sections of rats that received verapamil at a dose of $80 \mathrm{mg} /$ $\mathrm{kg}$ for 4 weeks. A single intravenous or oral dose of verapamil $5 \mathrm{mg} /$ $\mathrm{kg}$ slightly decreased necrosis in rat liver. Fibrosis model is induced by high fat diet, alcohol and $\mathrm{CCl}_{4}$ [39] through inhibition of $\mathrm{Ca}^{2+}$ degeneration and DNA damage.

It is well known that calcium has an important role in a number of cell functions, such as differentiation, proliferation, contraction, migration, apoptosis, and protein synthesis [40]. When hepatocytes were impaired by chemical poisons as $\mathrm{CCl}_{4}$ and ethanol, the $\left[\mathrm{Ca}^{2+}\right]$ ions increased causing cell depolarization, augmentation of excitability, and release of large amounts of inflammatory factor, thus resulting in activation of Kupffer cells and HSCs [41]. Hepatocytes of plasma membrane contain $\mathrm{Ca}^{2+}$ channels which admit $\mathrm{Ca}^{2+}$ in response to receptor-operated channel agonists. The receptor-operated $\mathrm{Ca}^{2+}$ channels allow various divalent cations to enter the hepatocyte [42]. Verapamil inhibit $\mathrm{Ca}^{2+}$ entry into liver cells through its effect on receptor-operated channels [43]. The study demonstrated that verapamil blocks the initiating agent of hepatic fibrosis by inhibiting the activation of HSCs. Verapamil act as vasodilator and has effect on blood vessels in the liver as it prevents hypertension and hypoxia in liver cells, and as an angiotenic, it can increase the local blood circulation and oxygen supply, thus inhibiting lipid peroxidation which is a major cellular mechanism involved in $\mathrm{CCl}_{4}$ hepatotoxicity, and thereby limiting hepatonecrosis and fibrogenesis $[12,44]$. This action could improve the oxygenation of the centrilobular region of the liver lobule. It also has the ability to scavenge free radicals [45].

\section{Histochemical discussion}

Glycogen granules were observed by PAS stain depending on the intensity of the coloured compound formed which is directly proportional to the glycogen content of the cell. Periodic acid is an oxidizing agent which breaks the $\mathrm{C}-\mathrm{C}$ bond between two adjacent hydroxyl groups. Tissues containing vicinal glycol groups or their amino or alkyl amino derivatives are oxidized by periodic acid to form dialdehydes, which combine with Schiff's reagent to form an insoluble magenta compound. In the present study, rats treated with ethanol$\mathrm{CCl}_{4}$ depleted glycogen granules. Transformation of a liver cell into a cancer cell occurs with characteristic depletion of the glycogen content. 
Citation: Waer HF, Nomani NA, Elbealy ER (2012) Ameliorated Effects of Verapamil on Hepatotoxicity Induced by Ethanol and Carbon Tetrachloride. J Cytol Histol 3:142. doi:10.4172/2157-7099.1000142

Among toxic changes associated with the process of carcinogenesis is depletion of glycogen granules [46]. Centrilobular glycogen depletion would appear to play a definite role in the sequence of changes which result in liver damage, cirrhosis and possibly tumours. Histochemical images of glycogen granules showed improvement by filling the cytoplasm of hepatocytes in groups treated with verapamil. As a calcium ion influx inhibitor, verapamil acts on calcium channel causing calcium entry block and prevent the effect of calcium on phosphorylase kinase enzyme, thus it had the ability to ameliorate the glycogen granules in 40 and $80 \mathrm{mg}$ doses gradually.

DNA histochemical technique established in the field of analytical cellular pathology is used as an important parameter providing significant information about the biological behaviour of cells [38]. DNA contents were classified as tetraploid, diploid and anaploid, based on the amount of DNA relative to the normal control where anaploidy increases with increasing stage of tumour [47]. DNA histochemical technique provides ploidy that result due to direct visualization and selection of cancer cells [38].

In the present study, DNA appeared to be increased in rats treated with ethanol- $\mathrm{CCl}_{4}$ in comparison with the control group. The changes in the nuclear structure induced by $\mathrm{CCl}_{4}$ involved a compensatory increase in nucleogenesis due to the decrease in the activity of the protein-synthesizing apparatus in hepatocytes, moreover, atypical hyper-chromatin was detected in hepatic cells and ethanol caused condensation of chromatin [48].

In this study, DNA appeared to show fragmentation. Ethanol induced apoptosis in liver cells and DNA fragmentation by intracellular $\mathrm{Ca}^{2+}$ elevation in the cytoplasm. Also $\mathrm{CCl}_{4}$ caused accumulation of $\mathrm{Ca}^{2+}$ in the nucleus and produced $\mathrm{Ca}^{2+}$ endonuclease fragmentation of DNA. The degree of DNA fragmentation correlates with the amount of $\mathrm{Ca}^{2+}$ in the nucleus [49]. In confirmation to the above, the nuclear compartment is the site of $\mathrm{Ca}^{2+}$ overload during toxic cell death and DNA is an important target undergoing lethal cleavage by $\mathrm{Ca}^{2+}$ stimulated endonuclease [50]. Nuclear fragmentation subsequently breaks down into multiple small parts as apoptotic bodies. One of the hallmarks of apoptosis is the cleavage of chromosomal DNA into nucleosomal units [51]. The Present study showed that DNA contents seemed to be improved in the group treated with $40 \mathrm{mg}$ verapamil, normal mitotic figures can be observed in group that treated with 80 $\mathrm{mg}$ verapamil. This may be due to the fact that calcium channel blocker verapamil protected the nuclear DNA against ethanol and $\mathrm{CCl}_{4}$ by acting on voltage-sensitive channel which lead to decrease $\mathrm{Ca}^{2+}$ entry into cells and prevention of DNA fragmentation by Ca- endonuclease activation [51].

Further studies were done in this work to evaluate and confirm the above finding. The serum activity of Aspartate aminptransferase (AST) and Alanine aminotransferase (ALT) were indicators of hepatotoxicity. AST levels fluctuated in response to the extent of cellular necrosis (cell death) and therefore may be temporarily and minimally elevated early in the disease process, and extremely elevated during the most acute phase. AST and ALT analyses showed high significant increase in $\mathrm{CCl}_{4}$ treated groups. This explains the destruction and areas of necrosis found in sections of this group examined by electron microscope [5254]. Gradual dose dependant amelioration were seen in other groups treated by verapamil and examined either by electron microscope or by biochemical analysis. Moreover, ultrastructure examination of the liver section from rats treated with $\mathrm{CCl}_{4}$ and ethanol showed increased amount of collagen fibers. This was clearly detected biochemically, hydroxyproline analysis showed a highly significant increase while in groups treated with 40 and $80 \mathrm{mg}$ verapamil showed gradual decrease respectively [55]. This may be due to fact that hydroxyproline is significantly reduced by calcium channel blocker induced by $\mathrm{CCl}_{4}[56]$. It is also clearly observed that lipid droplets were increased in liver sections treated by $\mathrm{CCl}_{4}$ and examined by electron microscope. These findings were in parallel to biochemical plasma cholesterol analyses which showed a high significant increase of plasma cholesterol [57]. Verapamil produced the most significant reduction in cholesterol level. This may be explained on the basis that verapamil has a strong ability to chelate multivalent metal ions especially zinc, calcium and iron. Alternatively its ability to chelate minerals has been reported to have some protective effect such as decreasing iron- mediated free radical formation and lowering serum cholesterol, lipid peroxide in experimental animals [58]. These statements were clearly observed in our electron and biochemical detection.

In conclusion it can be stated that in spite of the idea the verapamil had bad side effects, it has been found that it has an ameliorating effect on liver fibroses induced by alcohol and $\mathrm{CCl}_{4}[59]$.

\section{References}

1. Schuppan D, Ruehl M, Somasundaram R, Hahn EG (2001) Matrix as a modulator of hepatic fibrogenesis. Semin Liver Dis 21: 351-372.

2. Schuppan D, Afdhal NH (2008) Liver cirrhosis. The Lancet 371: 838-851.

3. Diehl AM (2002) Liver disease in alcohol abusers: clinical perspective. Alcohol 27: 7-11.

4. Wu D, Cederbaum Al (2003) Alcohol, oxidative stress, and free radical damage Alcohol Res Health 27: 277-284.

5. limuro Y, Bradford BU, Yamashina S, Rusyn I, Nakagami M, et al. (2000) The glutathione precuroser L-2-oxothiazolidine-4-carboxylic acid protects against liver injury due to chronic enteral ethanol exposure in the rat. Hepatol 31: 391 398.

6. Bhattacharya H, Lun L, Gomez R (2005) Biochemical Effects to Toxicity of CCl on Rosy Barbs (Puntius conchonius). J Our Nature 3: 20-25.

7. Ohta Y, Kongo M, Sasaki E, Nishida K, Ishiguro I (2000) Therapeutic effect of melatonin on carbon tetrachloride-induced acute liver injury in rats. J Pineal Res 28: 119-126.

8. Zangar RC, Benson JM, Burnett V (2000) Cytochrome P450 2E1 is the primary enzyme responsible for low-dose carbon tetrachloride metabolism in human liver microsomes. Chem Biol Interact 125: 233-243.

9. Arezzini B, Lunghi B, Lungarella G, Gardi C (2003) Iron overload enhances the development of experimental liver cirrhosis in mice. Int J Biochem Cell Biol 35:486-495.

10. Sermsappasuk P, Abdelrahman O, Weiss M (2007) Modeling cardiac uptake and negative inotropic response of verapamil in rat heart: effect of amiodarone. Pharm Res 24: 48-57.

11. Bellamy WT (1996) P-Glycoproteins and Multidrug Resistance. Annu Rev Pharmacol Toxicol 36: 161-183.

12. Xu D, Wu Y, Liao ZX, Wang $H$ (2007) Protective effect of verapamil on multiple hepatotoxic factors-induced liver fibrosis in rats. Pharmacol Res 55: 280-286.

13. Humason GL (1979) Animal tissue techniques. WH Freeman and Co, San Francisco

14. Douglas EC, Roberson RW (2009) Bioimaging: current concepts in light and electron microscopy. Jones and Barrlett pupishers, LLC.

15. Reitman S, Frankel S (1957) A colorimetric method for the determination of serum glutamate oxaloacetic and glutamate pyruvic transaminase. Am J Clin Pathol 28: 56-63.

16. Jena BS, Das S, Patnaik BK (1995) Effect of age on lipid peroxidation in a short-lived species of reptile. Arch Gerontol Geriatr 20: 263-272. 
Citation: Waer HF, Nomani NA, Elbealy ER (2012) Ameliorated Effects of Verapamil on Hepatotoxicity Induced by Ethanol and Carbon Tetrachloride. J Cytol Histol 3:142. doi:10.4172/2157-7099.1000142

17. Beale RN, Croft D (1962) The determination of cholesterol in serum J Clin Path 15: 221-227

18. Ajith TA, Janardhanan KK (2002) Antioxidant and antihepatotoxic activities of Phellinus rimosus (Berk) Pilat. J Ethnopharmacol 3: 387-391.

19. Andican G, Gelisgen R, Unal E, Tortum OB, Dervisoglu S, et al. (2005) Oxidative stress and nitric oxide in rats with alcohol-induced acute pancreatitis. World J Gastroenterol 11: 2340-2345.

20. Ravagnan L, Roumier T, Kroemer G (2002) Mitochondria, the killer organelles and their weapons. J Cell Physiol 192: 131-137.

21. Lieber CS (2005) Metabolism of alcohol. Clin Liver Dis 9: 1-35.

22. Okovityı̆ SV, Arkad'eva AV, Bezborodkina NN, Sakuta GA, laroslavtsev Mlu, et al. (2007) New protective effect of simvastatin in rats with experimental steatohepatitis. Eksp Klin Farmakol 70: 43-45

23. Weber LE, Boll M, Stampfl A (2003) Hepatotoxiccity and mechanism of action of halloalkanes: carbon tetrachloride as a toxicological model. Crit Rev Toxico 33: 105-136.

24. Neuschwander-Tetri BA, Caldwell SH (2004) Nonalcoholic steatohepatitis: summary of an AASLD Single Topic Conference. Hepatol 37: 1202-1219.

25. Calabrese F, Pontisso P, Pettenazzo E, Benvegnù L, Vario A, et al. (2000) Liver cell apoptosis in chronic hepatitis $C$ correlates with histological but not biochemical activity or serum HCV-RNA levels. Hepatol 31: 1153-1159.

26. DeLeve LD, Wang X, Hu L, McCusky MK, McCusky RS (2004) Rat liver sinusoidal endothelial cell phenotype is maintained by paracrine and autocrine regulation. Am J Physiol Gastrointest Liver Physiol 287: 757-763.

27. Corpechot C, Carrat F, Bonnand AM, Poupon RE, Poupon R (2000) The effect of ursodeoxycholic acid therapy on liver fibrosis progression in primary biliary cirrhosis. Hepatol 32: 1196-1199.

28. Siegmund SV, Dooley S, Brenner DA (2005) Molecular mechanisms of alcoholinduced hepatic fibrosis. Dig Dis 23: 264-274.

29. Doh KO, Jung HK, Moon IJ, Kang HG, Park JH, et al. (2008) Prevention of $\mathrm{CCl} 4$-induced liver cirrhosis by ribbon antisense to transforming growth factorbeta1. Int J Mol Med 21: 33-39.

30. Doonan F, Cotter TG (2008) Morphological assessment of apoptosis. Methods 44: $200-204$

31. Wang X (2001) The expanding role of mitochondria in apoptosis. Genes Dev 15: $2922-2933$

32. Krysko DV, Vanden Berghe T, D'Herde K, Vandenabeele P (2008) Apoptosis and necrosis: detection, discrimination and phagocytosis. Methods 44: 205221.

33. Nagy J (2000) Alcohol dependence at the cellular level: effects of ethanol on calcium homeostasis of IM-9 human lymphoblast cells. J Stud Alcohol 61: 225231.

34. Serviddio G, Bellanti F, Vendemiale G, Altomare E (2011) Mitochondria dysfunction in nonalcoholic steatohepatitis. Expert Rev Gastroenterol Hepatol 5: 233-244.

35. Susin SA, Zamzami N, Kroemer G (1998) Mitochondria as regulators of apoptosis: doubt no more. Biochim Biophys Acta 1366: 151-165.

36. Ding WX, Nam Ong C (2003) Role of oxidative stress and mitochondria changes in cyanobacteria-induced apoptosis and hepatotoxicity. FEMS Microbiol Lett 220: 1-7.

37. Elmore S (2007) Apoptosis: a review of programmed cell death. Toxicol Pathol 35: $495-516$

38. Hengartner MO (2001) Apoptosis. DNA destroyers. Nature 412: 27-29.

39. Chen M, Xu D, Hu XL, Wang $H$ (2008) Effects of liver fibrosis on verapamil pharmacokinetics in rats. Clin Exp Pharmacol Physiol 35: 287-294.

40. Brette F, Leroy J, Le Guennec JY, Salle L (2006) Ca2+ currents in cardiac myocytes: Old story, new insights. Prog Biophys Mol Biol 91: 1-82.

41. Yee HF Jr (2001) Ca2+ and rho signaling pathways: two paths to hepatic stellate cell contraction. Hepatology 33: 1007-1008.

42. Comporti M, Arezzini B, Signorini C, Sgherri C, Monaco B, et al. (2005) F2- isoprostanes stimulate collagen synthesis in activated hepatic stellate cells: a link with liver fibrosis? Lab Invest 85: 1381-1391.

43. Barritt GJ, Chen J, Rychkov GY (2008) $\mathrm{Ca}(2+)$ - permeable channels in the hepatocyte plasma membrane and their roles in hepatocyte physiology. Biochim Biophys Acta 1789: 651-672.

44. Shafik AN, Khodeir MM, Gouda NA, Mahmoud ME (2011) Improved antifibrotic effect of a combination of verapamil and silymarin in rat-induced liver fibrosis. Arab J Gastroenterol 12: 143-149.

45. Bognár B, Ahmed S, Kuppusamy ML, Selvendiran K, Khan M, et al. (2010) Synthesis and study of new paramagnetic and diamagnetic verapami derivatives. Bioorg Med Chem 18: 2954-2963.

46. Kuimova MK, Chan KL, Kazarian SG (2009) Chemical imaging of live cance cells in the natural aqueous environment. Appl Spectrosc 63: 164-171.

47. Ganem NJ, Storchova Z, Pellman D (2007) Tetraploidy, aneuploidy and cancer Curr Opin Genet Dev 17: 157-162.

48. Neuman MG, Haber JA, Malkiewicz IM, Cameron RG, Katz GG, et al. (2003) Ethanol signals for apoptosis in cultured skin cells. Alcohol 26: 179-190.

49. Vosler PS, Sun D, Wang S, Gao Y, Kintner DB, et al. (2009) Calcium dysregulation induces apoptosis-inducing factorrelease: Cross-talk between PARP-1- and calpain- signaling pathways. Exp Neurol 218: 213-220.

50. Zhivotovsky B, Orrenius S (2011) Calcium and cell death mechanisms: a perspective from the cell death community. Cell Calcium 50: 211-221.

51. Lorenzo HK, Susin SA (2004) Mitochondrial effectors in caspase-independent cell death. FEBS Lett 557: 14-20.

52. Liu DW, Xiao YH, Li Q (2005) Effects of drug serum of anti-fibrosis I herba compound on calcium in hepatic stellate cell and its molecular mechanism. World J Gastroenterol 11: 1515-1520.

53. Hu YB, Li DG, Lu HM (2007) Modified synthetic siRNA targeting tissue inhibito of metalloproteinase-2 inhibits hepatic fibrogenesis in rats. J Gene Med 9: 217 229.

54. Saravanan R, Viswanathan P, Pugalendi KV (2006) Protective effect of ursolic acid on ethanol-mediated experimental liver damage in rats. Life Sci 78: 713 718.

55. Xu D, Wu Y, Liao ZX, Wang H (2007) Protective effect of verapamil on multiple hepatotoxic factors-induced liver fibrosis in rats. Pharmacol Res 55: 280-286.

56. Kim NY, Lee MK, Park MJ, Kim SJ, Park HJ, et al. (2005) Momordin Ic and oleanolic acid from Kochiae Fructus reduce carbon tetrachloride induced hepatooxicity in rats. J Med Food 8: 119-183.

57. Melin AM, Perromat A, Deleris G (2001)Fourier-transform infrared spectroscopy: a pharmacotoxicologic tool for in vivo monitoring radical aggression. Can $\mathrm{J}$ Physiol Pharmacol 79: 158-165

58. Adeneye AA, Benebo AS, Agbaje EO (2007) Protective effect of the aqueous leaf and seed extract of Phyllanthus amarus on alcohol-induced hepatotoxity in rats. West Afr J Pharmacol Drug Res 22: 42-50.

59. Malgorzata T, Szelag A (2007) The role of calcium channel-blocking drugs in preserving rat liver for transplantation. Adv Clin Exp Med 5: 609-618. 